\title{
HUBUNGAN PENGETAHUAN DENGAN KEAKTIFAN IBU DALAM MEMBAWA ANAK USIA 1-5 TAHUN MELAKUKAN PENIMBANGAN DI WILAYAH KERJA POSYANDU LILI KABUPATEN MEMPAWAH TAHUN 2018
}

\author{
Elise Putri ${ }^{1}$, Katarina Iit $^{2}$
}

Akademi Kebidanan Panca Bhakti Pontianak

Email korespondensi: akbidpbpontianak@gmail.com

\begin{abstract}
Abstrak
Deteksi tumbuh kembang bayi, balita dan anak pra sekolah adalah kegiatan pemeriksaan untuk menemukan secara dini adanya penyimpangan tumbuh kembang bayi, balita dan anak pra-sekolah. Dengan penimbangan balita secara teratur dan terus-menerus, bila ada kelainan yang terdapat pada balita dapat diamati dan ditentukan sedini mungkin, dan sekaligus menentukan tindak lanjutnya. Tujuan penelitian ini untuk mengetahui ada hubungan atau tidak ada hubungan antara pengetahuan dengan keaktifan ibu dalam membawa anak usia 1-5 tahun melakukan penimbangan di Posyandu Lili Kabupaten Mempawah Tahun 2018. Metode penelitian desain penelitian yang digunakan dalam penelitian ini adalah deskriptif korelasi dengan pendekatan cross sectional. Tempat penelitian Posyandu Lili. Populasi dalam penelitian ini 123 ibu yang memiliki anak usia 1-5 tahun dengan sampel 35 diambil dari 25\% jumlah populasi dan ditambah drop out $10 \%$. Teknik pengambilan sampel menggunakan teknik purposive sampling. Hasil yang didapatkan adalah penelitian yang didapatkan dari 35 responden bahwa sangat sedikit dari responden yang memiliki pengetahuan kurang yaitu 2 orang $(5,7 \%)$ dan sebagian besar dari responden berpengetahuan cukup tentang membawa anak usia 1-5 tahun melakukan penimbangan yaitu sebanyak 21 orang (60\%). Dan keaktifan yang didapatkan bahwa sebagian dari responden tidak aktif dalam membawa anak usia 1-5 tahun melakukan penimbangan yaitu sebanyak 18 orang (51,4\%). Dan hasil perhitungan Chi Square yaitu 1,92< 5,991. Dengan demikian $x^{2}$ hitung $<x^{2}$ tabel maka $H_{0}$ diterima dan $\mathrm{H}_{\mathrm{a}}$ ditolak sehingga dinyatakan bahwa tidak ada hubungan antara pengetahuan dengan keaktifan ibu dalam membawa anak usia 1-5 tahun melakukan penimbangan di Posyandu Lili Kabupaten Mempawah Tahun 2018. Saran untuk tempat penelitian adalah supaya bisa menjadi masukan bagi posyandu, kader dan tenaga kesehatan untuk menyarankan ibu membawa anak usia 1 5 tahun melakukan penimbangan secara teratur setiap bulan di Posyandu Lili.
\end{abstract}

Kata Kunci: Pengetahuan, Keaktifan, Tumbuh Kembang, Bayi dan Balita

\section{Pendahuluan}

Posyandu merupakan salah satu bentuk upaya Kesehatan Bersumber daya Masyarakat (UKBM) yang di kelola dan di selenggarakan dari untuk dan bersama masyarakat dalam penyelenggaraan pembangunan kesehatan, guna memberdayakan masyarakat dan memberikan kemudahan kepada masyarakat dalam memperoleh pelayanan kesehatan dasar untuk mempercepat penurunan angka kematian ibu dan bayi (KemenKes, 2011).

Menurut UNICEF (United Nations International Chilldren's Emergency Fund), Indonesia merupakan negara yang mempunyai

\footnotetext{
${ }^{1}$ Dosen Akademi Kebidanan Panca Bhakti Pontianak

${ }^{2}$ Dosen Akademi Kebidanan Panca Bhakti Pontianak
}

jumlah balita terhambat pertumbuhan dan perkembangannya paling besar 7,7 juta balita (DepKes, 2010).

Deteksi tumbuh kembang bayi, balita dan anak pra sekolah adalah kegiatan pemeriksaan untuk menemukan secara dini adanya penyimpangan tumbuh kembang bayi, balita dan anak pra-sekolah. Dalam penilaian pertumbuhan pada setiap anak, sebaiknya dilakukan penimbangan atau pengukuran berat badan dan tinggi badan yang teratur jaraknya, sekaligus pertambahan usia kronologis dengan pola pemberian jenis makanan balita. Dengan 
penimbangan balita secara teratur dan terusmenerus, bila ada kelainan yang terdapat pada balita dapat diamati dan ditentukan sedini mungkin, dan sekaligus menentukan tindak lanjutnya (Maryunani, 2010).

Terdapat berbagai cara untuk mengikuti pertumbuhan anak secara teratur. Salah satu yang dapat dilakukan secara mudah adalah dengan memantau berat badan anak menurut tinggi badannya, pengukuran ini adalah salah satu cara untuk mengetahui status gizi anak. Dengan melakukan pengukuran ini secara teratur, dapat diketahui keadaan gizi anak sehingga dapat dipakai sebagai salah satu alat pemantau pertumbuhan fisik anak (Syafrudin, 2011).

Menurut data dari Kementrian Kesehatan Republik Indonesia tahun 2015 cakupan penimbangan balita di Indonesia dari tahun 2010 sampai tahun 2014 di Indonesia cenderung meningkat. Namun pada tahun 2015 terjadi penurunan menjadi $73,0 \%$, hal itu disebabkan pada tahun 2015 terjadi peralihan RPJMN (Rencana Pembangunan Jangka Menengah Nasional) tahun 2015-2019 dimana terdapat pengembangan sasaran program dan penambahan indikator baru terkait Kementrian Kesehatan sehingga cakupan dan target penimbangan balita di posyandu belum tersosialisasikan dengan baik (Kemenkes RI, 2015).

Menurut data yang diperoleh dari Dinas Kesehatan Kalimantan Barat, jumlah Posyandu yang berada di Kalimantan Barat yaitu 253 terdiri dari Posyandu Pratama 50 (13, 4\%), Madya 144 (38, 6\%), Purnama 51 (13, 7\%), Mandiri $8(2,1 \%)$ dan jumlah Posyandu yang aktif di wilayah Kalimantan Barat yaitu 59 $(23,3 \%)$ sehingga belum mencapai target pada tahun 2012 (Dinas Kesehatan Kalimantan Barat, 2012).

Menurut Kementerian Kesehatan tahun 2015, peran serta masyarakat dalam penimbangan balita menjadi sangat penting dalam deteksi dini kasus gizi kurang dan gizi buruk. Dengan rajin menimbang balita, maka pertumbuhan balita dapat dipantau secara intensif. Sehingga bila berat badan anak tidak naik ataupun jika ditemukan penyakit akan dapat segera dilakukan upaya pemulihan dan pencegahan supaya tidak menjadi gizi kurang atau gizi buruk. Semakin cepat ditemukan, maka penanganan kasus gizi kurang atau gizi buruk akan semakin baik. Penanganan yang cepat dan tepat sesuai tata laksana kasus gizi buruk akan mengurangi risiko kematian sehingga angka kematian akibat gizi buruk dapat ditekan. Tindak lanjut dari hasil penimbangan selain penyuluhan juga pemberian makanan tambahan dan pemberian suplemen gizi (Kemenkes RI, 2015).

Dalam rangka meningkatkan cakupan pelayanan kesehatan kepada masyarakat berbagai upaya dengan memanfaatkan potensi sumber daya yang ada di masyarakat telah lama dilakukan dalam bentuk Upaya Kesehatan Bersumber daya Masyarakat (UKBM). Posyandu merupakan salah satu bentuk UKBM yang telah lama dikembangkan untuk menjangkau pelayanan kesehatan bagi masyarakat. Pencapaian tertinggi dicapai oleh Kabupaten Melawi sebesar 41,7\%, Kabupaten Bengkayang 39,5\%, Kabupaten Pontianak 37,4\%, Kabupaten Sanggau 35,8\%, Kabupaten 
Sambas 32,2\%, Kabupaten Sintang 31,2\%, Kabupaten Ketapang 23,5\%. Kabupaten Kubu Raya 23,5\%, Kabupaten Landak 23,4\%, Kabupaten Kapuas Hulu 20,6\%, Kabupaten Kayong Utara 12,0\%, Kabupaten Singkawang 11,8\%, Kabupaten Mempawah 6,8\%, dan Kabupaten Sekadau 4,3\% (Dinas Kesehatan Kalimantan Barat, 2015)

Hasil studi pendahuluan yang dilakukan peneliti pada bulan Februari terhadap petugas kesehatan di Daerah Kabupaten Mempawah ada 5 Posyandu yang kurang aktif yaitu di Posyandu Kencana ada $46 \%$ balita yang datang ke Posyandu, Posyandu Sanggar Mamiri ada 41\% balita yang datang ke Posyandu, Posyandu Lili ada $17 \%$ balita yang datang ke Posyandu, Posyandu Beringin 1 ada $28 \%$ balita yang datang ke Posyandu, Posyandu Tanjung ada $39 \%$ balita yang datang ke Posyandu.

Berdasarkan studi pendahuluan yang dilakukan peneliti di Wilayah Kerja Posyandu Lili yang ada di Kabupaten Mempawah dengan teknik wawancara pada 2 orang. Dari segi pengetahuan di dapatkan hasil 2 orang responden yang memilki pengetahuan kurang mengerti pentingnya menimbang anak usia 1-5 tahun. Alasan lainnya dari 2 orang responden tersebut adalah kurangnya dukungan keluarga terutama suami untuk membawa anak usia 1-5 tahun menimbang ke Posyandu, dan jarak tempuh rumah masyarakat ke posyandu yang berkisar jauh sehingga ibu enggan membawa balita melakukan penimbangan ke Posyandu.

Dari uraian tersebut maka peneliti tertarik untuk melakukan penelitian tentang hubungan pengetahuan dengan keaktifan ibu dalam membawa anak usia 1-5 tahun melakukan penimbangan di Wilayah Kerja Posyandu Lili Tahun 2018.

\section{Metode}

Metode penelitian desain penelitian yang digunakan dalam penelitian ini adalah deskriptif korelasi dengan pendekatan cross sectional. Penelitian dilakukan di Posyandu Lili. Populasi dalam penelitian ini 123 ibu yang memiliki anak usia 1-5 tahun dengan sampel 35 diambil dari $25 \%$ jumlah populasi dan ditambah drop out 10\%. Teknik pengambilan sampel menggunakan teknik purposive sampling dan uji korelasi menggunakan chi square.

\section{Hasil dan Pembahasan}

Tabel 1. Analisa Univariat

\begin{tabular}{lcc}
\hline \multicolumn{1}{c}{ Kategori } & $\mathrm{N}$ & $\%$ \\
\hline Pengetahuan & 2 & 5,7 \\
Kurang & 21 & 60 \\
Cukup & 12 & 34,3 \\
Baik & & \\
Keaktifan & 17 & 48,6 \\
Aktif & 18 & 51,4 \\
Tidak Aktif & & \\
\hline
\end{tabular}


Dari tabel di 1 diatas dapat disimpulkan bahwa sangat sedikit dari responden yang memiliki pengetahuan kurang yaitu 2 orang $(5,7 \%)$ dan sebagian besar responden berpengetahuan cukup yaitu 21 orang (60\%).
Sedangkan pada kategori keaktifan, dapat disimpulkan bahwa sebagian dari responden yang tidak aktif yaitu 18 orang $(51,4 \%)$ dalam membawa anak usia 1-5 tahun melakukan penimbangan di Posyandu Lili.

Tabel 2. Analisa Bivariat

\begin{tabular}{|c|c|c|c|c|c|}
\hline \multirow{3}{*}{ Pengetahuan } & \multicolumn{4}{|c|}{ Keaktifan } & \multirow{3}{*}{$X^{2}$} \\
\hline & \multicolumn{2}{|c|}{ Tidak aktif } & \multicolumn{2}{|c|}{ Aktif } & \\
\hline & $\sum$ & $\%$ & $\sum$ & $\%$ & \\
\hline Kurang & 1 & 50 & 1 & 50 & \\
\hline Cukup & 9 & 42,9 & 12 & 57,1 & 1,92 \\
\hline Baik & 8 & 66,7 & 4 & 33,3 & \\
\hline
\end{tabular}

Tabel 2 diatas menunjukkan hasil perhitungan Chi Square sebesar 1,92 sedangkan angka pada tabel Chi Square tahap signifikan 5\% adalah 5,991. Dengan demikian $\mathrm{x}^{2}$ hitung < $\mathrm{x}^{2}$ tabel maka $\mathrm{H}_{0}$ diterima dan $\mathrm{H}_{\mathrm{a}}$ ditolak yaitu $1,92<5,991$ sehingga dari hasil perhitungan dinyatakan bahwa tidak ada hubungan antara pengetahuan dengan keaktifan ibu dalam membawa anak usia 1-5 tahun melakukan penimbangan di Posyandu Lili Kabupaten Mempawah Tahun 2018.

Menurut Notoatmodjo (2010), pengetahuan adalah hasil penginderaan manusia, atau hasil tahu seseorang terhadap objek melalui indera yang dimiliki nya (mata, hidung, telinga, dan sebagainya). Dengan sendirinya, pada waktu penginderaan sampai menghasilkan pengetahuan tersebut sangat dipengaruhi oleh intensitas perhatian dan persepsi terhadap objek. Sebagian besar pengetahuan seseorang diperoleh melalui indra pendengaran (telinga), dan indra penglihatan (mata). Pengetahuan seseorang terhadap objek mempunyai intensitas atau tingkat yang berbeda-beda.
Menurut Pemberdayaan Kesehatan Keluarga (PKK) (1999) dalam Zulkarnain (2013) penimbangan adalah kegiatan yang bertujuan untuk memonitoring balita dengan melihat naik atau tidak berat badan dengan menggunakan alat timbang berupa dacin, yang dilakukan sebulan sekali dengan menggunakan Kartu Menuju Sehat (KMS). Penimbangan merupakan salah satu pelaksanaan kegiatan posyandu dalam rangka mengoptimalisasi potensi tumbuh kembang anak.

Hasil penelitian ini tidak sejalan dengan peneliti yang dilakukan oleh Mudawamah (2017) mengenai Hubungan Antara Pengetahuan Tentang Posyandu Dengan Keaktifan Ibu Dalam Kegiatan Posyandu Di Desa Simo Kecamatan Kradenan Kabupaten Grobongan tahun 2017 yang menyebutkan bahwa dengan pengetahuan baik sebanyak 54 orang $(66,7 \%)$.

Berdasarkan hasil penelitian dari 35 responden dapat dilihat bahwa sebagian besar dari responden berpengetahuan cukup yaitu 21 orang $(60 \%)$ hal ini disebabkan karena tingkat pendidikan yang menengah, dan sudah 
mendapatkan penyuluhan tentang pentingnya manfaat penimbangan di posyandu.

Bardasarkan teori menurut Suliha (2002) dikutip dalam Lestari (2009) tingkat pendidikan individu dan masyarakat dapat berpengaruh terhadap penerimaan pendidikan kesehatan. Pendidikan orang tua merupakan salah satu faktor yang penting dalam tumbuh kembang anak, karena dengan pendidikan yang baik, maka orang tua dapat menerima segala informasi dari luar terutama tentang cara pengasuhan anak yang baik, bagaimana menjaga kesehatan anaknya, pendidikannya dan sebagainya.

Menurut Dinas Kesehatan (2010), tentang menimbangkan balita yaitu balita ditimbang satu tahun atau minimal 8 kali setahun di Posyandu. Berdasarkan pengertian diatas maka dapat disimpulkan bahwa kehadiran Balita dikategorikan menjadi dua yaitu aktif apabila anak balita hadir dalam kegiatan penimbangan balita di Posyandu sebanyak lebih dari atau 8 kali dalam satu tahun dan tidak aktif apabila kurang dari 8 kali dalam satu tahun.

Hasil penelitian ini sejalan dengan peneliti yang dilakukan oleh Mudawamah mengenai Hubungan Antara Pengetahuan Tentang Posyandu Dengan Keaktifan Ibu Dalam Kegiatan Posyandu Di Desa Simo Kecamatan Kradenan Kabupaten Grobongan tahun 2017. Berdasarkan hasil penelitian didapatkan 44 responden $(54,3 \%)$ dengan kategori tidak aktif.

Ibu yang memiliki anak usia 1-5 tahun dan yang tidak aktif dalam membawa anak usia 1-5 tahun melakukan penimbangan di Posyandu disebabkan karena rendahnya tingkat pemahaman ibu akan manfaat posyandu disamping itu kesadaran ibu untuk membawa anaknya keposyandu kurang yang dipengaruhi oleh kesibukan ibu. Mayoritas kesibukan ibu balita yang bekerja yang terkait oleh jam kerja sehingga tidak memiliki waktu luang untuk membawa anaknya ke posyandu yang akhirnya memilih untuk tidak datang ke Posyandu dan jarak untuk melakukan penimbangan di Posyandu yang jauh.

Dari hasil analisis bivariat dan perhitungan Chi Square terhadap antara pengetahuan dengan keaktifan dalam membawa anak usia 1-5 tahun melakukan penimbangan di posyandu. Hasil perhitungan nya $\mathrm{x}^{2}$ hitung $<\mathrm{x}^{2}$ tabel maka $\mathrm{H}_{0}$ diterima dan $\mathrm{H}_{\mathrm{a}}$ ditolak yaitu $1,92<5,991$ sehingga dari hasil perhitungan dinyatakan bahwa tidak ada hubungan antara pengetahuan dengan keaktifan ibu dalam membawa anak usia 1-5 tahun melakukan penimbangan di Posyandu Lili Kabupaten Mempawah Tahun 2018.

Hasil penelitian ini tidak sejalan dengan hasil penelitian yang dilakukan oleh Mudawamah (2017) mengenai Hubungan Antara Pengetahuan Tentang Posyandu Dengan Keaktifan Ibu Dalam Kegiatan Posyandu Di Desa Simo Kecamatan Kradenan Kabupaten Grobongan tahun 2017. Berdasarkan hasil uji Chi-Square menunjukkan nilai signifikansi $\rho$ sebesar $(0,001)$. Nilai $\rho<0,05$ maka diputuskan bahwa $\mathrm{H}_{\mathrm{o}}$ ditolak $\mathrm{H}_{\mathrm{a}}$ diterima, sehingga dapat disimpulkan bahwa terdapat hubungan antara pengetahuan tentang Posyandu dengan keaktifan ibu dalam kegiatan posyandu di Desa 
Simo Kecamatan Kradenan Kabupaten Grobogan.

\section{Kesimpulan}

Berdasarkan hasil penelitian yang ditemukan, maka dapat disimpulkan bahwa, sebagian besar responden berpengetahuan cukup tentang membawa anak usia 1-5 tahun melakukan penimbangan yaitu sebanyak 21 orang (60\%), sebagian dari responden tidak aktif dalam membawa anak usia 1-5 tahun melakukan penimbangan yaitu sebanyak 18 orang $(51,4 \%)$ dan pada Analisa bivariat disimpulkan bahwa tidak ada hubungan antara pengetahuan dengan keaktifan ibu dalam membawa anak usia 1-5 tahun melakukan penimbangan di Posyandu Lili Kabupaten Mempawah Tahun 2018. Saran untuk tempat penelitian adalah supaya bisa menjadi masukan bagi posyandu, kader dan tenaga kesehatan untuk menyarankan ibu membawa anak usia 15 tahun melakukan penimbangan secara teratur setiap bulan di Posyandu Lili.

\section{Daftar Pustaka}

Departemen Kesehatan RI. 2010. Pedoman Perilaku Hidup Bersih dan Sehat. Jakarta: Kementrian Kesehatan Republik Indonesia

Dinas Kesehatan Provinsi Kalimantan Barat. 2012. Profil kesehatan Kalimantan Barat Tahun 2015. Pontianak: Dinas Kesehatan

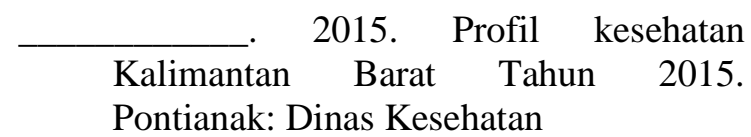

Kalimantan Barat Tahun 2015. Pontianak: Dinas Kesehatan

Kementrian Kesehatan Republik Indonesia. 2011. Pedoman umum pengelolaan Posyandu. Jakarta: Kementrian Kesehatan Republik Indonesia

2015. Rencana Strategis Kementrian Kesehatan Tahun 20152019. Jakarta: Kementrian Kesehatan RI

Lestari, Lilik Indah. 2009. Hubungan Antara Karakteristik Ibu Balita Dengan Kunjungan Balita Dalam Kegiatan Posyandu Di Kelurahan Genuksari Kecamatan Genuk Kota Semarang Tahun 2009.

http://lib.unnes.ac.id/111/1/6073.pdf diakses: 20 februari 2018, 15.20 WIB

Maryunani, Anik. 2010. Ilmu Kesehatan Anak, Jakarta: CV. Trans Info Media

Mudawamah, Hanik. 2017. Hubungan Antara Pengetahuan Tentang Posyandu Dengan Keaktifan Ibu Dalam Kegiatan Posyandu Di Desa Simo Kecamatan Kradenan Kabupaten Grobongan http://eprints.ums.ac.id/53608/16/NASK AH\%20PUBLIKASI\%20REVISI\%202. pdf diakses: 20 Mei 2018, 21.20 WIB

Notoatmodjo. 2010. Metodologi Penelitian Kesehatan. Jakarta: PT. Rineka Cipta

Syafrudin. 2011. Penyuluhan Kesehatan Pada Remaja, Keluarga, Lansia dan Masyarakat. Jakarta: Trans Info Media

Zulkarnain. 2013. Motivasi Ibu Pada Penimbangan Balita Di Posyandu Puskesmas Petanang Lubuk Linggau. http://jurnal.stikesbhaktihusada.ac.id diakses: 25 Februari 2018, 21.10 WIB 